\title{
Transnational knowledge in social work programs: \\ Challenges and strategies within assisted voluntary return and reintegration support ${ }^{1}$
}

\author{
Ine Lietaert ${ }^{2}$ \\ Social Work and Social Pedagogy, Ghent University, Gent, Belgium \\ Centre for the Social Study of Migration and Refugees (CESSMIR), Ghent University, Gent, Belgium
}

\begin{abstract}
The nexus between migration research and social work research led to interesting impulses to study transnational social work practices. However, the practical terms of being involved in crossborder programs are understudied. This article aims to transcend the preserving national and western-centric orientation in social work research by investigating assisted voluntary return and reintegration (AVRR) support. Drawing on interviews and group discussions with social workers supporting returnees in host countries and countries of origin, I set out to reveal the challenges that this practice poses within the Belgian AVRR program. The findings showed that the Belgian social workers were confronted with a lack of transnational knowledge to fulfill their roles, resulting from a division between different practitioners within the support chain and the localization of the main focus of the support across borders. Furthermore, the data shed light onto the struggles with regard to social workers' positions within the program and towards its goals. For the Belgian social workers, this is related to their place within a restrictive migration policy. For the social workers in the countries of origin it was mainly linked to the transnational character of the program. Viewing these findings, I reflect on their implications for the provision of AVRR support and transnational support practices.
\end{abstract}

\section{Introduction}

Almost all social workers nowadays encounter clients with a migration background and thus deal with migration and mobility issues (Barberis \& Boccagni, 2014; Vuille, Bolzman, \& Durrett, 2013). However, the concept of migration remains underexplored in social work research. There is insufficient attention for the ways in which mobility and migration affect and challenge social work's strategies, its organizational structures, and even its very nature and identity (Boccagni, Righard, \& Bolzman, 2015; Lorenz, 2004; Williams \& Graham, 2014). A valuable change was brought about by the recent nexus between social work research and migration research, especially by focusing on the debate of "transnationalism" (Levitt \& Glick Schiller, 2004). In this article, I illustrate how the introduction of the transnational perspective in the study of social work improves our understandings of social work with migrants. However, I argue that the practical terms of being involved in transnational social support (Chambon, Schröer, \& Schweppe, 2013) and its implications for social work have been overlooked so far.

\footnotetext{
${ }^{1}$ Based on Lietaert, I. (2017). Transnational knowledge in social work programs: Challenges and strategies within assisted voluntary return and reintegration support. Transnational Social Review. 


\section{Social work and migration: The transnational perspective}

The concept of transnationalism in migration research refers to the possible influence of the continuing ties that migrants and their descendants maintain across national borders (Levitt \& Glick Schiller, 2004). This transnational perspective led to an evolution from locating migration research within a specific nation-state (Wimmer \& Glick Schiller, 2003), to a focus on the simultaneous commitment of migrants in multiple societies. Furthermore, research has focused on how transnational ties potentially lead to the formation of transnational identities and to participation in transnational economic, familial, political, religious, and sociocultural activities (Levitt \& Jaworsky, 2007; Smith \& Guarnizo, 1998). Also, return migration is increasingly researched from a transnational perspective, e.g. the concept of "transnational return" expresses that "[r]eturn processes are characterized by and constructed through hybrid and highly individual [...] remigration decisions, including transnational patterns" (Olivier- Mensah \& SchollSchneider, 2016, p. 2), while it also needs to be recognized that the transnational social field is highly selective and stratified, and "in the case of [...] returnees, strongly determined by their migration trajectory" (Lietaert, Broekaert, \& Derluyn, 2016a, p. 11). Applying insights from this transnational perspective when studying social work practices challenges assumptions and practices of social work with migrants in innovative ways.

First, it exposes the sedentarist conceptualizations and essentialized assumptions of society and people inherent to the ontology of social work, which has always been a field of research and practice closely connected with the broader process of nation-state building (Lorenz, 2004; Righard \& Boccagni, 2015). With sedentarism as a reference point, migrants are regarded as clients who are "uprooted" and need to be embedded in the receiving society. This results in social work practices that are typically limited to nation-state borders. Second, a focus on migrants' possible cross-border ties and practices enables the framing of clients' needs, obligations, and vulnerabilities as anchored in two or more settings in different countries and on the consequences of such transnational ties for social work practices (Baldassar \& Merla, 2013; Chambon et al., 2013; Vuille et al., 2013). Third, the findings on the tacit assumptions within the social work profession and the methodological and organizational implications of clients' transnational realities come together in discussions on "transnational social work." Transnational social work is defined as an emerging field of practice designed to serve transnational populations, operates across nation-state boundaries, and addresses complex transnational problems and dilemmas (Negi \& Furman, 2010). A transnational model of social work facilitates understandings of how clients' connections with different countries can be interlinked in multidirectional processes in their daily lives and how this impacts social problems and social work practice. It also points to the need of developing social work practices on "both 'sides' of migrant life experience - that is, in receiving and in sending communities" (Righard \& Boccagni, 2015, p. 12), the need for crossborder collaboration between practices in different countries, and essentially the development and institutionalization of translocally anchored practices (Boccagni et al., 2015).

However, while the conceptual and analytical stance of this transnational optic is clear and translocally anchored practices are set as a way forward to social work with migrants, there is still little insight into how social workers engage, or can or should act in transnational social work programs. This article sets out to investigate the challenges social workers face and the strategies they employ when delivering support within the context of an assisted voluntary return and reintegration (AVRR) program. 
AVRR programs are developed by governments of migrants' host countries in order to increase migrants' willingness to return and facilitate the sustainability of their return by providing administrative, logistical, financial, and social support to migrants to return and to reintegrate in their country of origin (International Organization for Migration (IOM), 2016). This support is a practice with a high degree of transnational connection: it includes translocal face-to-face interventions, whereby the support to migrants who enter the program starts in the host country and continues after the migrants' return to the country of origin. This paper studies the implementation of AVRR support in Belgium. In this context, the AVRR program is strongly institutionalized, and many social workers are involved in its implementation (Lietaert, Broekaert, \& Derluyn, 2016b). Therefore, the Belgian AVRR program presents one of the sole forms of institutionalized transnational social work.

Various researchers have criticized AVRR programs, stating that they operate as "involuntary return programs" within migration management goals and pointing at the absence of a definition and monitoring of "reintegration" or "sustainable return" and, consequently, questioning their contribution to returnees' reintegration and the sustainability of their return (Blitz, Sales, \& Marzano, 2005; Cassarino, 2008; Koser \& Kuschminder, 2015; Van Houte, 2014). While these elements obviously pose struggles for social workers involved in AVRR programs, this article aims at placing the analytic focus on the challenges that may emerge from the organization of this support across national borders. Developing a more clear view on the professional and practical difficulties within these specific practices can enlarge the knowledge on the demands that adopting a transnational approach poses for social workers and consequently enhance understandings of social work with migrants. Moreover, by including the perspectives of social workers in both receiving and sending countries, I aim to transcend the prevailing national and western-centric orientation in social work research. In what follows, I first present the content and structure of the Belgian AVRR program before turning to the empirical study and its findings. The article ends with a reflection on the implications of these findings for AVRR support and for transnational social work.

\section{The Belgian AVRR program}

\section{Content of the program}

The Belgian AVRR program is coordinated by the Federal Agency for the Reception of Asylum Seekers (Fedasil) and supports asylum seekers, rejected asylum seekers, and undocumented migrants in returning to their country of origin (Fedasil, 2009). The content of the support gradually expanded over the years and nowadays consists of two layers of support (Lietaert et al., 2016b). First, "travel support," outsourced to IOM, enables the physical return of migrants. This travel support consists of two elements: pre-departure counseling and payment of travel-related costs (flight ticket and luggage) (Fedasil, 2009). Second, the extra layer of "reintegration support" may be added. The Belgian government has contracted two "reintegration providers," IOM and Caritas International Belgium (hereafter referred to as Caritas Belgium), to implement this support through their international networks in the countries of origin. Reintegration support aims at facilitating small-scale, individual projects that help returnees to restart their lives and to reintegrate in the country of origin. It consists of guidance before (by a Belgian reintegration counselor) and after return (by a local organization in the country of origin). Clients are attributed a reintegration budget that can be used for training and schooling, for legal, administrative, or psychological support, for job placement, accommodation, furniture, transport, medical support, 
and income-generating activities (Fedasil, 2010). This reintegration budget consists of 700 euro per person (maximum 1750 euro per family) and can be increased with 1500 euro for returning migrants who want to start a microbusiness. Research has indicated that this financial support is valued by returnees, however, due to the difficult conditions in countries of origin, few returnees are able to create a sustainable livelihood with this amount of financial support (Lietaert, 2016; Van Houte, 2014). Moreover it has to be noted that not all migrants who return within the Belgian voluntary return program receive additional reintegration support. An increasing number of migrants only receives travel support (Lietaert et al., 2016b). For these returnees, the support chain ends upon arrival in the country of origin.

\section{Role of the different caseworkers in the Belgian support chain}

According to Fedasil (2013), providing post-return reintegration support makes returning to the country of origin accessible for a broader group of migrants, yet it also makes the organization of the support more complex. It created the need for specialized guidance to prepare return and reintegration. In the Belgian context, this resulted in a stepwise, gradually specializing support chain (see Figure 1).

Figure 1: Chain of the different actors involved in the Belgian AVRR program

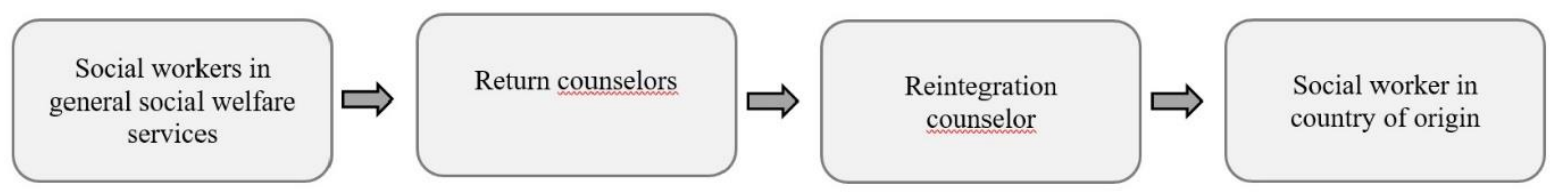

In the first step of the pre-return support in Belgium for migrants residing outside federal reception centers, namely in local reception initiatives (LRI) or outside the official reception structures, social workers in general social welfare services are expected to introduce the topic of voluntary return to their clients and refer them to a return counselor for further support. For social workers employed in LRIs, this task is formalized within the "return trajectory" that was introduced in the reception of asylum seekers in 2012. The goal of this return trajectory is to explicitly include a focus on return counseling in the reception of asylum seekers (Fedasil, 2012). Fixed moments are prescribed in which social workers in LRIs need to discuss the topic of voluntary return. If the client is interested, the social worker refers them to a regional return counselor. These are Fedasil employees who have an office in large cities in Belgium and support those migrants who are still in an LRI and migrants who reside outside official reception structures. When an asylum request is rejected and the client needs to leave the LRI, the social worker needs to refer the client to an "open return place" in a federal asylum centrum. In such return places, a person can stay for 30 days and receives specialized and intensive return preparation from the return counselor of the asylum center.

Return counselors (regional return counselors in Belgium or return counselors in Belgian asylum centers) further discuss the return, prepare the application for travel support and make a referral to a reintegration counselor when additional reintegration support is wanted, needed, and warranted. A reintegration counselor is a staff member of the (trans)national organizations Caritas Belgium or IOM Brussels. The reintegration counselor informs the returnee about the scope and conditions of the support, determines the amount of the reintegration budget, prepares a 
reintegration plan with the client, and discusses the reintegration support together with their local partners in the countries of origin.

After return, a practitioner in the country of origin gives the returnee administrative and financial support and guidance on how to use the allocated reintegration budget (Fedasil, 2013). Reintegration support comprises "in-kind" support, which means that the returnee does not receive his/her reintegration budget in cash. The purchases and payments of goods and services with the reintegration budget of the returnee are done by, or together with, the local practitioner after a joint reevaluation of the reintegration plans as set before return (Caritas International, 2014; Fedasil, 2010). The profile of these local practitioners differs and varies between the two reintegration providers and within different countries of origin. In this study, data were collected through the network of Caritas Belgium and their local partners in post-Soviet countries. Caritas Belgium works with social workers to implement the reintegration support in this return region, based on the conviction that besides the necessary needs assessment, budget management, and support for purchasing goods, the profile of the social worker within this job warrants a social guidance throughout the whole return process (Caritas International, 2013). As the expertise of these local partners thus lies in "social guidance," the business assistance is outsourced to external business consultants who coach returnees throughout the set-up of their income-generating activity. The general guidance and follow-up of the program stays with the Caritas partner. The reintegration support lasts from six months up to one year after return.

\section{Methods}

\section{Study setting}

This study focuses on social workers in general social welfare services who need to introduce and discuss the topic of AVRR (hereafter referred to as Belgian social workers), and the social workers in the countries of origin providing reintegration support (hereafter referred to as local social workers). By doing so, I scrutinize the first and last step of the chain in the Belgian AVRR program and include the social workers in this support system who are geographically and temporarily most distant, yet are still expected to work in one program. Moreover, these chains both involve first-line social works (as opposed to the more specialized return and reintegration counselors) employed in national organizations (as opposed to reintegration counselors working in transnational organizations) which, I argue, could unmask more clearly how AVRR programs as transnational support programs challenge social workers.

Since the process of return migration and the provision of AVRR support is strongly influenced by the context in host countries and countries of origin (Lietaert, 2016), I opted for a country-specific approach and studied return migration from Belgium to a specific region of return (Caucasus, Russia, and Central Asia). Most countries in this region are characterized by a high emigration rate, which has markedly intensified over recent decades (Caritas International, 2013). Natural disasters, armed conflicts, and the socio-political crisis after the collapse of the Soviet Union led to mass emigration from different post-Soviet states in the late 1990s, mainly to the Russian Federation (which makes Russia, as the most popular destination for ex-USSR nationals, an exception to this process of emigration), but also to western Europe and elsewhere. Although large regional differences exist, the situation in many places in this region is characterized by a poor socio-economic situation, high unemployment rates, an important influence of clientelism in the job market, a climate of corruption, strong barriers for small-scale businesses, unaffordable or unavailable healthcare, and unstable political conditions. These elements still form important 
causes of emigration, and also barriers for the reintegration process of returnees (Falkingham, 2005; Karklins, 2002). An in-depth exploration of the return experiences and the experiences of returnees with AVRR support is beyond the scope of this paper, but this information can be consulted elsewhere (see Lietaert, 2016). The small sample of social workers and its contextualization within a certain host country and region of return does not allow any generalization of the findings. However, the study does offer an opportunity to portray the challenges and strategies linked to providing support in a transnational social work program.

\section{Data collection and analysis}

Data on the perspectives of the Belgian social workers were collected in the frame of a master thesis (Bliki, 2015)1. Through the use of semi-structured qualitative interviews, social workers working in general social welfare services $(n=15)$ were asked about their role, the challenges, and their strategies with regard to AVRR support. The data on the perspectives of local social workers were collected through a longitudinal study among the local partners of Caritas Belgium in Armenia and Georgia (Lietaert, 2016). From January 2012 until July 2013, nine field visits were conducted, during which the researcher (the author) made detailed field notes about social workers' guidance of 85 returnees and on conversations with the social workers about their everyday practices in assisting returnees. In a semi-structured interview with the Armenian and the Georgian social workers at the end of the support period, these practitioners were asked to reflect on their job and on the challenges they were confronted with. In these interviews, "markers" (Neuman, 2006) out of the field notes (e.g. examples of observed difficulties or struggles during the guidance) were used for further discussion. In order to fully address the research question of this article, these data were complemented with information from two group discussions, held during a regional meeting of the local partner of Caritas Belgium in Yerevan, Armenia (2012) and Tbilisi, Georgia (2016). During these regional meetings, local social workers of different post-Soviet countries came together to discuss the implementation of the Belgian AVRR program and to reflect on the main challenges when implementing reintegration support.

All participants were informed about the research aims and the conditions of anonymity and confidentiality of the study, and a mix of written and oral informed consent was used. After receiving consent, all interviews in this study were audiotaped and transcribed literally. During the group discussions, detailed notes were taken, which were written out immediately afterwards. Thematic analyses were used to analyze these data (Guest, MacQueen, \& Namey, 2012). In a first step, the data sets of the Belgian and local social workers were analyzed separately to uncover the challenges, difficulties, and strategies when guiding (potential) returnees before return or providing reintegration support after return. For this purpose, the interviews were coded using the code-and-retrieve software program NVivo10 to organize the data into various categories of challenges that could be linked with the transnational character of the support. In a second step, the two coding trees were linked and I looked for related challenges and strategies beyond the national borders, which resulted in a clustering of the findings around challenges regarding the need for (transnational) knowledge and the positioning of the social workers. In a last step, as presented in the final section, I reflected on how these challenges were linked to tensions within the profession of social work and on their implications for the field of social work with undocumented migrants and transnational social work. 


\section{Challenges and strategies when providing pre- and post-return support}

To get a better understanding on what challenged social workers when providing return and reintegration support, we first needed to know how they conceived their role within the AVRR program. There was a general agreement among the Belgian social workers that it suited their task and professional role to address the topic of voluntary return within their daily contact with asylum seekers, rejected asylum seekers, and/or undocumented migrants. Informing a client about the possibilities to return voluntarily and receive assistance was linked to enabling people to make informed choices and supporting them to take control of their lives and increase their wellbeing (Ferguson, 2003). Return was described as a "burdened topic" and deciding to return as "a difficult process" in which people needed to cope with feelings of loss, with the emotionally heavy process of disengaging from envisioned goals, and in which they needed support. It was noticed that the adversity and complexity of this process was not always recognized within the program (Vandevoordt, 2016). The local social workers described their task of providing reintegration support as combining three roles. First, they have the executing role of controlling the expenditure of the budget in accordance with the project rules and collecting the required proofs. Second, they take up the role of counselor by conducting a needs assessment and searching, together with the returnee, for the best possible way to use their budget. Third, they function as a person of trust, someone the returnee can turn to in the challenging process of restarting life after return migration.

Although the content of the work of Belgian and local social workers within this translocally anchored support process is not easily comparable, both were confronted with various challenges which could be linked to the need for transnational knowledge and their place within a transnational program with restrictive migration policy goals.

\section{Lack of feedback and connection: The need for (transnational) knowledge}

Throughout all the pre-return interviews, the Belgian social workers narrated about the substantial lack of knowledge they experienced when supporting clients with regard to return. They experienced a paradox between their task to approach the topic of return and open up the imaginary of return migration as an actual option on the one hand and a lack of knowledge on the content and the functioning of the AVRR program and the realities in countries of origin on the other hand. The respondents related this lack of knowledge to (1) the fact that they only encountered this theme sporadically; (2) the complexity of the AVRR program with varying amounts of support and complicated eligibility criteria; (3) the way the AVRR support is organized (stepwise and specialized) and the lack of feedback between the different levels in the support chain; and (4) the fact that they needed to discuss and prepare future support practices that are implemented across borders. The last two elements will be further elaborated, as these are two elements that are linked to the transnational character of the support.

The introduction of a specialized and stepwise support chain created a clear "next step" in the support process. This was described by some respondents as "an improvement" or "a reassurance that something is there." Yet the specialization also led to a loss of touch with the theme and a minimization of the feeling of responsibility towards the topic. It enforced a justification for a certain reluctance to provide this type of support that "should be done by specialists" (Masocha, 2014):

I do not witness this last phase, the file is taken over by people who are specialized in return. I do not have the feeling that I work on return migration. I am preoccupied with other issues. 
Moreover, there is a lack of connection and feedback between the different levels of this support chain. Several respondents stated that they refer to a return counselor without knowledge of what this person will be discussing with their clients. Consequently, they could not pass this information on to their clients, which does not seem conductive to creating interest in the option of return migration. Other research indicated that this lack of knowledge is also true the other way around: within this gradual pre-return support system, the specialized Belgian return counselors have no insight either into social workers' everyday encounters with potential returnees in the host country and the distress and emotionality that comes with the envisioning of an unwanted return (Vandevoordt, 2016). Also, not knowing what happened to their clients after referral to an open return place resulted in the presumption amongst several social workers that "voluntary return does not work": "I think most of them disappear into illegality, but actually, I don't know," "I think it is just a media event," or "you sometimes see figures of how many people returned to which countries, I always presume that none of my clients is amongst them."

As there was already no connection with the next step in Belgium, many respondents stated they had no idea about what happened after return and described reintegration support as "one big question mark":

Reintegration support? I really have no idea what I should envision about that. What does this guidance contain? Is it a social worker from here or there? Are they really helping people?

When a respondent conceived his/her role as being confined to informing and referring clients, this lack of knowledge was not always problematized: "We receive little feedback because voluntary return actually is a project that is detached from migrants' stay in Belgium." Many others described the same lack of knowledge, yet argued that receiving feedback on what happens after return, whether it be success stories or difficulties, would improve their abilities to discuss the topic. The respondents also referred to their lack of knowledge about the cross-border contexts and realities in the countries of origin. The distance between the Belgian social worker and the countries of origin sometimes caused the respondents to resign themselves to the fact that it is impossible to know: "I have never been there [...] it is just so far away." Although a social worker in the host country cannot have a thorough insight into the context of the countries of origin of each client, an argument that supports the need for specialization in the frame of return counseling, this element of not being able to "act as expert" in the relationship with clients seemed to paralyze some of the respondents (Masocha, 2014). Some social workers argued that when the client states that it is impossible to return, not knowing the reality in the country of origin meant that they had "nothing to say in this discussion" as "these people also know that I don't know." This lack of knowledge about the content of the program across the border and the broader realities in countries of origin, what I refer to as transnational knowledge (Köngeter, 2013), raised big doubts about the genuineness, feasibility, and added value of this support. The portrayed doubts and even disbeliefs made it so that the respondents did not conceive and approach voluntary return as a realistic option for their clients. Furthermore, they expressed the feeling that they could not reassure the clients' fears and worries during this difficult decision by any means:

I mention voluntary return but I have no clue if it really goes like I am saying. I have already my doubts about it, let alone a client who needs to decide to [...].

One respondent explained how she overcame difficulties with regard to the lack of transnational knowledge by contacting a Belgian reintegration counselor to gain information about the conditions in a specific country of origin before engaging in a conversation on voluntary return with a client. In this way she felt able to give realistic information on what could be done after 
return. Further, the respondent explained that she accompanies the person to the first meeting with the reintegration counselor, and "when they feel safe there, we leave it further to them." Accompanying the client to the next level instead of merely referring them was done to reduce fear and resistance towards AVRR and to make clients feel that they can always turn back to the social worker even when the guidance is passed on. Finally, she argued that currently it is "easy and financially feasible" to stay in touch with clients through e-mail. This was done to accompany people who returned with "this feeling of safety": to give the returnee the possibility to contact his/her Belgian social worker after return. This approach of continuing the relationship with clients throughout the return process and beyond provided this Belgian social worker with insight into the next step of guidance and the realities of returned clients and made her feel able to provide pre-return counseling:

The people whom we guided to return with reintegration support are not doing bad. It is not simple, it is again living in a country where things are different, with different kind of dangers where they can fall into, but they were able to do something with this project.

While most Belgian social workers clearly lacked the transnational knowledge on realities beyond the Belgian borders, various local social workers had experienced opportunities for gaining knowledge on the host country's context and were involved in transnational exchange. They participated in a yearly meeting in Brussels, organized by Caritas Belgium, where different local partners are invited to discuss the content and development of the AVRR program, to exchange experiences, to meet Belgian social workers from the partner network, and to visit reception facilities for asylum applicants (Caritas International, 2014). The latter was especially valued by the local social workers as it gave them insight into the context of the Belgian host country. They argued that this knowledge was essential as it enlarged their understandings of the experiences of the returnees they are guiding and facilitated their relationship and their collaboration with the returnees.

\section{A challenging positioning within migration policy and a transnational program}

The interviews and group discussions revealed great challenges with regard to social workers' position within the program and towards its goals. Although all Belgian social workers subscribed to having a role with regard to AVRR, several respondents questioned the extent of this role. The pre-return interviews revealed that these doubts resulted in a wide variety of approaches to the topic. Some respondents would only address the topic of voluntary return when a client asked for more information and stressed that this happened very sporadically, which was interpreted as "proof that clients have no interest in this option." Others systemically informed each client about voluntary return, often stimulated by the recently introduced formal instruction to do so (cf. supra), yet they refrained from any further initiatives besides referring to the next step. They experienced that, when return was brought up, it was often immediately rejected by their client. Readdressing the topic when firmly declined by their clients would equalize "pushing" or "convincing" to return. And doing so would contribute to the restrictive policies of migration management, something that they strongly felt the need to refrain from: "it stays their decision." From this point of view, the client only needed to be informed about the possibility to return with AVRR support. When there is an interest, the next step can be taken by the client. In this approach, a well-informed client is responsible and accountable for his/her own decisions, and the availability of specialized support relieves the social worker from any responsibility (Masocha, 2014). 
However, the same belief that the decision to return should be made by the client him/herself was reflected in a totally different approach among other respondents. Some respondents approached their task in pre-return support as informing clients, stimulate reflection on the possibility to return and on wider future goals, and accompany them through this process. The interviews revealed various strategies and conditions to discuss the topic and to support the client within this process, such as "taking time" and "sensing the right time" to discuss return; reverting to the topic at different moments; "respecting clients own pace" in thinking through the option of return; having a trustful relationship as a precondition to touch upon AVRR; and continuing the relationship with the client by staying available within the return decision process (and beyond) regardless of its outcome and regardless of clients' (changing) legal status. These temporal and relational conditions did not only facilitate the task to approach return, they were also described by some respondents as important elements to preserve the voluntariness of clients' choice. Remarkably, the confrontation with organizational constraints that prevented the creation of these temporal and relational conditions, and working in a context where pushing factors to return are explicitly and consciously embedded in the way the support is organized, seemed to result for several respondents in a withdrawal of pre-departure support, to prevent a personal stake in pushing migrants to return, as this conflicts with their personal and professional values.

Local social workers in the countries of origin seemed to struggle with establishing their place too. They experienced difficulties with positioning themselves within a framework and goals of a program created by foreign governments, but taking place in a very different, transnational setting. First, the local social workers were confronted with rejections or doubts from their clients with regard to their professional role within the program. The respondents described difficulties with "positioning them as social workers." Although the returnees were well acquainted with the task and role of a social worker, as most returnees had encountered many social work professionals during their stay in Belgium, they had no trust in a compatriot filling such a role. The respondents reported that at the outset of the guidance they often needed to surmount the high distrust evoked by the idea that they, a local social worker, would manage the reintegration. This shows that the concept of social support cannot simply be transferred from western states to the context of post-Soviet countries where social work is a relatively new profession and the public domain is characterized by a general atmosphere of distrust and corruption (An, 2014; Karklins, 2002). In line with this, several respondents stated they had difficulties delineating a "professional relationship" with returnees and "keep sufficient distance," missing tools, education, and frameworks for doing so.

Second, the local social workers struggled to position themselves within this "Belgian program." As a first point, the local social workers often struggled to stand up to their clients. When returnees regarded them as "mere executors of the Belgian program," they often approached the local social worker only to "demand their money." In such cases, the respondents felt they lacked the authority to negotiate the best use of the reintegration support with the returnee and needed to search for ways to emphasize their roles toward the returnees:

Sometimes I am very angry because they are so sure that they have money and they say, I want this and I want that. Come on! Just stop. And talk to me! Ok, yes, Belgium gave you money. I don't want to say that I decide for $100 \%$, but, I am deciding too.

According to the respondents, the strong transnational connection they have with their Belgian reintegration partner is needed to clarify their role and responsibility in the AVRR program, and could even be reinforced by showing this connection clearly through prereturn Skype contact with 
all three parties involved: reintegration counselor, local social worker, and returnee. Further, they argued that "there are often people coming from Belgium who do not need reintegration support," however, they have no say in this, as access to support is decided by the Belgian government. The eligibility criteria for social support are set by the host countries' return program in order to stimulate return, thus conflicting sometimes with the local social workers' professional ethics that require support to be given to people in need. Some expressed reluctance to have a say in deciding who should receive support. More discretion in a setting with limited resources could place them in a difficult position, giving them "the freedom to decide which one of a range of equally 'needy' people receives a service" (Evans \& Harris, 2004, p. 889) and putting them at risk of being accused of favoritism (Evans, 2013). Finally, the narratives of the local social workers point to the challenge of realizing reintegration support within a program of a foreign government that disregards the structural conditions returnees face in their country of origin. The economic and political realities in the countries of origin made it very difficult to start up a sustainable business with the provided reintegration budget (Falkingham, 2005). As one respondent framed so sharply:

We all know that the budget is not high enough to start a business with. The smaller the budget, the higher the risk that the business will fail, and the instability and corruption in the country make everything unpredictable.

The local social workers sometimes expressed strong feelings of powerlessness when they were confronted with unfair but unchangeable political and infrastructural constraints: reintegration support could by no means solve political problems returnees might have, and social workers could not change the difficult access to medical treatment in the country. By pointing at the structural obstacles they are confronted with while providing reintegration support, they questioned the goal as set by AVRR programs to stimulate sustainable (economic) reintegration within the non-recurring, short-term, and individualized support of the AVRR program.

\section{Concluding remarks}

This paper investigated the challenges that the cross-border practice of AVRR support poses for the social workers in host countries who have to introduce the topic of voluntary return to clients and for the social workers in the countries of origin who support the reintegration process of returnees. Reflecting on the implications of the findings for the AVRR support and for transnational social work, two main concluding points can be made.

First, the findings showed that although AVRR support is a practice that includes translocal faceto-face interventions, the boundaries of social work practices limited by state borders are still strongly present. The borders between the different nations involved in the program were transcended. The Belgian international organizations coordinating the reintegration support created a strong interconnection and transnational exchange between returnees, the Belgian reintegration counselor in the host country, and the local social worker in the country of origin. Instead, boundaries were mainly situated within the host country with the strong division between support to integrate in the host society and support linked to reintegration in the country of origin. This division created a lack of knowledge about, connection with, and experience with issues that transcend the national context (Williams \& Graham, 2014), even amongst Belgian social workers working solely with migrants.

I argue that these boundaries need to be overcome to enable social workers in generalist social services in host countries to engage with the topic of return migration and to include a nuanced 
and multidimensional reading of their clients' needs and future prospects (Righard \& Boccagni, 2015). The results showed how this can be done by the interlinked elements of creating a connection between the different levels of the AVRR support chain and acquiring an essential minimum of transnational knowledge. The connection between the levels in the Belgian AVRR program should no longer depend on the personal initiative of the social worker but be a central element in the program and a responsibility of both the generalist social workers and the specialized Belgian return or reintegration counselors. This connection can be created by accompanying a client to the next step, as this enlarged social workers' knowledge and was perceived as supportive by the client. Return and reintegration counselors in the host country, on their part, should be attempting to involve the Belgian social workers at least during the first stage of the continued guidance, and essentially create systematic transnational feedback loops. Such loops should not only contain general "return stories," but need to provide the Belgian social workers with feedback on outcomes for specific clients. Williams and Graham posed that in order to interconnect social work with mobilities, "social workers need to be well versed in social policy and legislative requirements, migration theory and policy, welfare entitlements and the system, able to work crossnationally and attuned to the profession's ethical responsibilities" (Williams and Graham, 2014, pp. i12-i13). Adding the need for transnational knowledge to this extensive summary might evoke the feeling that the list of requirements for social work with migrants just becomes endless and unattainable. I certainly do not plead for any specialization or expert knowledge. However, engaging in transnational support practices demands an effort to actively insert knowledge that transcends the national context, or in the words of Boccagni et al. (2015), a certain "transnational sensitivity." Moreover, it calls for the courage to recognize the knowledge of the client. I argue that clients' expertise on their country of origin does not minimize the social worker in the host country's ability to engage in a conversation or nullify any (other) knowledge the social worker has. On the contrary, creating a space for reflection on future options demands an active engagement in trying to understand the (transnational) lifeworlds of their clients (Righard \& Boccagni, 2015) and a partnership with clients in building joined knowledge (Williams \& Graham, 2014). Equally important for local social workers guiding returnees after return, a transnational orientation in their support demands insight into and acknowledgement of the migration experiences as part of their clients' lifeworlds.

Second, the results showed the struggles of both Belgian and local respondents to position themselves within the transnational social work program. Besides the inherent difficulty of the theme of return migration, for the Belgian social workers this struggle mainly related to the element of working with migrants without legal citizenship, the limited choices they have, and the elements of force within return decisions arising from the migration management goals linked to the AVRR program (Lietaert et al., 2016b). Research already indicated that social workers are often caught between the requirements and eligibility criteria for social support related to a client's residence status and professional ethics that require support to be given to people in need, needs that are often caused by a lack of residence documents and/or (full) citizenship (Cuadra \& Staaf, 2014). Clearly, there is a link here with the ambiguous nature of social work in general as a profession operating between the state and the individual, mediating between support and control (Lorenz, 2004). However, this tension between the aspiration of the individual and the collective welfare is amplified within the work with migrants without legal documents. Where the element of control for citizens of a nation-state is implemented, in theory to accomplish their inclusion into society and societal norms, the element of control within migration management explicitly excludes them from societies and nation-states. What is more, the interviews indicated 
that the compulsory elements within AVRR, and the feeling of not wanting to be part of it, led some respondents to step back and shift responsibility. It can be questioned whether such a withdrawal leads in any way to an increase of the voluntariness of clients' choice to return. I argue for an active and critical engagement of first-line social workers with this topic and with the ethical challenges that stem from organizational structures, legal frameworks, and policy provisions and social work's orientation towards a social justice agenda (Bouverne-De Bie, Roose, Coussée, \& Bradt, 2014; Masocha, 2014), as currently such dilemmas seem to disappear from the AVRR program (Vandevoordt, 2016).

The struggles of the local social workers were more directly linked to the transnational character of the program. They illustrated the difficulties of building a social work practice within a transnational institutional context in a program in which modes and goals of a western European project are transferred to another context, joining critiques on imperialism when transferring western social work models (Gray, 2005). The AVRR program aims to continue the social support that started in Belgium in countries of origin, however it overlooks the different interpretation of social support and position of social work across borders (Brydon, 2012). Awareness is needed of the ways in which the local social workers interpret and (need to) transform the idea of "social counseling" to an approach practicable in their context in order to change the structures within the Belgian program that obstruct the realization of social support within the cross-border context. However, while this transnational exchange and adaption of the program is fundamental to the creation of qualitative support, the power imbalances within the transnational relations between actors in host countries and countries of origin need to be recognized (An, 2014). The struggles of the local social workers within this transnational program exactly illustrate the perpetuation of the western view on return migrants and their needs (Deepak, 2012). In this particular case of AVRR, the interest of the western states in stimulating return clearly prevails, causing the issue of reintegration to stay marginal in the hierarchy of governmental priorities (Cassarino, 2008). In a similar vein to the Belgian social workers, it urges local social workers to broach the discrepancies between the western-oriented design and goals of the AVRR program and the transnational realities (Åkesson \& Baaz, 2015). It endorses transnational social work to be founded on partnerships between the transnational actors and on the recognition of the reality of structural inequalities (Deepak, 2012) and points at the crucial role of the (trans)national reintegration partners to collect and reinforce the critical remarks of their local partners on the tendency to individualize and depoliticize the problems faced by these returnees (Geiger \& Pécoud, 2010; Lietaert, 2016).

\section{Note}

1. The author has the permission to use these data. 


\section{References}

Åkesson, L., \& Baaz, M. E. (2015). Africa's return migrants: The new developers. London, Uppsala: Zed Books, Nordiska Afrikainstutet.

An, S. (2014). Social work between westernization and nationalization - A transnational perspective on social work in post-socialist/post-soviet countries. In C. Bähr, H. Hans Günther, S. Christian, S. Wolfgang, \& S. Cornelia (Eds.), The world Atlas of social work (pp. 376-387). Weinheim/München: Beltz Juventa.

Baldassar, L., \& Merla, L. (2013). Transnational families, migration and the circulation of care: Understanding mobility and absence in family life. Oxford: Routledge.

Barberis, E., \& Boccagni, P. (2014). Blurred rights, local practices: Social work and immigration in Italy. British Journal of Social Work, 44(suppl 1), i70-i87.

Bliki, T. (2015). De visies van sociaal werkers op hun rol in begeleide vrijwillige terugkeer (Master thesis). Ghent University, Ghent.

Blitz, B. K., Sales, R., \& Marzano, L. (2005). Non-voluntary return? The politics of return to Afghanistan. Political Studies, 53, 182-200.

Boccagni, P., \& Righard, E. (2015). Introduction to the special issue: Social work and migration in Europe: A dialogue across boundaries. Journal of Immigrant \& Refugee Studies, 13, 221-228.

Boccagni, P., Righard, E., \& Bolzman, C. (2015). Mapping transnationalism: Transnational social work with migrants: Introduction. Transnational Social Review, 5, 312-319.

Bouverne-De Bie, M., Roose, R., Coussée, F., \& Bradt, L. (2014). Learning democracy in social work. In G. Biesta, M. Bouverne-De Bie, \& D. Wildemeersch (Eds.), Civic learning, democratic citizenship and the public sphere (pp. 43-54). Dordrecht: Springer.

Brydon, K. (2012). Promoting diversity or confirming hegemony? In search of new insights for social work. International Social Work, 55, 155-167.

Caritas International. (2013). The exchange of reintegration practices in the Caucasus, central Asia and Russia. Brussels: Caritas International.

Caritas International. (2014). 10 years reintegration support - Background paper. Brussels: Caritas International.

Cassarino, J.-P. (2008). Editorial introduction. International Journal on Multicultural Societies, 10, 95-105.

Chambon, A., Schröer, W., \& Schweppe, C. (2013). Transnational social support. New York \& London: Routledge.

Cuadra, C. B., \& Staaf, A. (2014). Public social services' encounters with irregular migrants in Sweden: Amid values of social work and control of migration. European Journal of Social Work, 17, 88-103.

Deepak, A. C. (2012). Globalization, power and resistance: Postcolonial and transnational feminist perspectives for social work practice. International Social Work, 55, 779-793.

Evans, T. (2013). Organisational rules and discretion in adult social work. British Journal of Social Work, 43, 739-758. 
Evans, T., \& Harris, J. (2004). Street-level bureaucracy, social work and the (exaggerated) death of discretion. British Journal of Social Work, 34, 871-895. doi:10.1093/bjsw/bch106

Falkingham, J. (2005). The end of the rollercoaster? Growth, inequality and poverty in Central Asia and the Caucasus. Social Policy \& Administration, 39, 340-360.

Fedasil. (2009). Programmes and strategies in Belgium fostering assisted voluntary return and reintegration in Third Countries. Brussels: European Migration Network.

Fedasil. (2010). Subsidiabiliteitsregels reïntegratiefonds. Brussels: Fedasil.

Fedasil. (2012). Instructie betreffende terugkeertraject en terugkeerplaatsen voor asielzoekers opgevangen in het opvangnetwerk van Fedasil. Brussels: Fedasil.

Fedasil. (2013). Brochure vrijwillige terugkeer voor maatschappelijk werkers. Brussels: Fedasil.

Ferguson, H. (2003). In defence (and celebration) of individualization and life politics for social work. British Journal of Social Work, 33, 699-707.

Geiger, M., \& Pécoud, A. (2010). The politics of international migration management. London: Palgrave Macmillan.

Gray, M. (2005). Dilemmas of international social work: Paradoxical processes in indigenisation, universalism and imperialism. International Journal of Social Welfare, 14, 231-238.

Guest, G., MacQueen, K., \& Namey, E. (2012). Applied thematic analysis. Thousand Oaks, California: Sage.

International Organization for Migration (IOM). (2016). Key migration terms. Retrieved from http://www.iom.int/key-migration-terms

Karklins, R. (2002). Typology of post-communist corruption. Problems of Post Communism, 49, 2232.

Köngeter, S. (2013). Paradoxes of transnational knowledge production in social work. In A. Chambon, W. Schröer, \& S. Schweppe (Eds.), Tansnational social support (pp. 187-210). New York \& London: Routledge.

Koser, K., \& Kuschminder, K. (2015). Comparative research on the assisted voluntary return and reintegration of migrants. Geneva: International Organization for migration.

Levitt, P., \& Glick Schiller, N. (2004). Conceptualizing simultaneity: A transnational social field perspective on society. International Migration Review, 38, 1002-1039.

Levitt, P., \& Jaworsky, B. N. (2007). Transnational migration studies: Past developments and future trends. Annual Review of Sociology, 33, 129-156.

Lietaert, I. (2016). Perspectives on return migration: A multi-sited, longitudinal study on the return processes of Armenian and Georgian migrants (Doctoral thesis). Ghent University, Ghent.

Lietaert, I., Broekaert, E., \& Derluyn, I. (2016a). The boundaries of transnationalism: The case of assisted voluntary return migrants. Global Networks: Advance online publication.

Lietaert, I., Broekaert, E., \& Derluyn, I. (2016b). From social instrument to migration management tool: Assisted Voluntary Return programmes - The case of Belgium. Social Policy \& Administration, Advance online publication. 
Lorenz, W. (2004). Towards a European paradigm of social work - Studies in the history of modes of social work and social policy in Europe (Doctoral dissertation). Technischen Universität Dresden, Dresden.

Masocha, S. (2014). We do the best we can: Accounting practices in social work discourses of asylum seekers. British Journal of Social Work, 44, 1621-1636.

Negi, N. J., \& Furman, R. (2010). Transnational social work practice. Columbia University Press.

Neuman, W. (2006). Social research methods: Qualitative and quantitative approaches. Boston, MA: Pearson Education.

Olivier-Mensah, C., \& Scholl-Schneider, S. (2016). Focus topic: Transnational return? Family constellations, expectations and negotiations in remigration. Transnational Social Review - A Social Work Journal, 6.

Righard, E., \& Boccagni, P. (2015). Mapping the theoretical foundations of the social work migration nexus. Journal of Immigrant \& Refugee Studies, 13, 229-244.

Smith, M. P., \& Guarnizo, L. E. (1998). Transnationalism from below (Vol. 6). New Brunswick: Transaction Publishers.

Van Houte, M. (2014). Moving back or moving forward? Return migration after conflict (PhD Dissertation). Maastricht Graduate School of Governance, Maastricht.

Vandevoordt, R. (2016). Judgement and ambivalence in migration work: On the (Dis) appearance of dilemmas in assisting voluntary return. Sociology, 1-16.

Vuille, M., Bolzman, C., \& Durrett, E. H. (2013). Professional stances and personal values in the realm of transnational family reunification with older parents: Social work practice in an emerging field. European Journal of Social Work, 16, 407-426.

Williams, C., \& Graham, M. (2014). 'A world on the move': Migration, mobilities and social work. British Journal of Social Work, 44, i1-i17. doi:10.1093/bjsw/bcu058

Wimmer, A., \& Glick Schiller, N. (2003). Methodological nationalism, the social sciences, and the study of migration: An essay in historical epistemology. International Migration Review, 37, 576610. 